\title{
The Impact of Lead and Nickel Environmental Pollution on Blood Levels of Liver Enzymes in House Sparrow (Passer domesticus) in Kosovo
}

\author{
Lulzim Millaku ${ }^{1}{ }^{,}$, Resmije Imeri $^{2}$, Jeton Orllati ${ }^{1}$, Artan Trebicka ${ }^{3}$ \\ ${ }^{1}$ Department of Biology, Mathematics \& Natural Science Faculty, University of Prishtina, Prishtina, Kosovo \\ ${ }^{2}$ Department of Biology, Agricultural \& Veterinary Faculty, University of Prishtina, Prishtina, Kosovo \\ ${ }^{3}$ Department of Biology, Natural Science Faculty, University of Tirana, Tirana, Albania \\ Email address: \\ lulzimmillaku@hotmail.com (L. Millaku)
}

\section{To cite this article:}

Lulzim Millaku, Resmije Imeri, Artan Trebicka. The Impact of Lead and Nickel Environmental Pollution on Blood Levels of Liver Enzymes in House Sparrow (Passer domesticus) in Kosovo. Animal and Veterinary Sciences. Vol. 3, No. 1, 2015, pp. 28-31.

doi: $10.11648 /$ j.avs.20150301.16

\begin{abstract}
The aim of this study was the evaluation of environmental pollution with heavy metals such as Lead and Nickel on the living organisms in industrial areas, using the blood of House sparrow (Passer domesticus) as a bio-indicator of pollution by metals. For this purpose, a blood collection was performed on 32 house sparrows (Passer domesticus) males and females, which were captured in Mitrovica town (situated close to smelter "Trepqa", closed in year 2000), Drenas town (near the Ferronickel smelter, pollution area) and in rural area (Ujmir village, not contaminated area). In blood plasma we have analysed: alkaline phosphatase (AP), plasma alanin aminotransferase (ALT), aspartat aminotransferase (AST) and total proteins (TP) in house sparrow (Passer domesticus). The results obtained indicate the different values of the enzymes activity (AP, ALT, AST) in blood sparrows between the localities studied. Higher values of AST in significant scale ( $<<0.001)$ were found in sparrows from Mitrovica and Drenas town compared with the reference site (Ujmirë village). Values of enzymes ALT, AP and total proteins are different between the analyzed groups but the differences are not significant. Further studies are warranted to investigate the mechanism of susceptibility of house sparrow to environmental pollution.
\end{abstract}

Keywords: Metals, House Sparrow, Biochemical Parameters

\section{Introduction}

The natural environment has been gradually contaminated by various forms of pollution. A serious group of pollutants are heavy metals that pose a threat to all living organisms, with lead being especially considered as highly toxic [1] Environmental levels of lead have increased more than 1,000 -fold over the past three centuries as a result of human activity. The greatest increase occurred between the years 1950 and 2000, and reflected increasing worldwide use of leaded gasoline. Lead is a heavy, low melting, bluish-gray metal that occurs naturally in the Earth's crust. Most lead used by industry comes from mined ores ("primary") or from recycled scrap metal or batteries ("secondary") [2]. Lead can enter the environment through releases from mining lead and other metals, and from factories that make or use lead, lead alloys, or lead compounds [3]. Nickel normally occurs at very low levels in the environment, so very sensitive methods are needed to detect nickel in most environmental samples. In the environment, it is primarily found combined with oxygen or sulfur as oxides or sulfides. Nickel is released into the atmosphere during nickel mining and by industries that make or use nickel, nickel alloys, or nickel compounds. These industries also might discharge nickel in waste water. Nickel is also released into the atmosphere by oil-burning power plants, coal-burning power plants, and trash incinerators. A lot of nickel released into the environment ends up in soil or sediment where it strongly attaches to particles containing iron or manganese. Under acidic conditions, nickel is more mobile in soil and might seep into groundwater. Nickel does not appear to concentrate in fish. Studies show that some plants can take up and accumulate nickel. However, it has been shown that nickel does not accumulate in small animals living on land that has been treated with nickel-containing sludge [2].

The use of living organisms to monitor heavy metal 
pollution provides more promising results than chemical and physical analysis. This results from the fact that we obtain accurate data of bioavailability and bio transference of contaminants as well as observe some physiological and behavioral symptoms of induced toxicity.

Most chemical analyses are conducted on plasma, although testing could also be performed on a serum sample. The reason for this is that collection of serum from birds frequently yields a very small sample size compared to what can be obtained from plasma. Plasma is preferred for routine blood biochemical evaluations of birds. Establishment of normal reference intervals for a given species of bird depends on many factors, including age, state of health, and nutrition. Because of the avian patient's ability to mask illness, it is often difficult to guarantee that a given bird is free of disease for inclusion into a population of normal healthy birds. Factors such as gender, age, temperature, humidity, photo period, season of the year, and time of day may influence the results of a particular analyze [4]. Many studies that are done in avian natural population, the different surroundings of lead and nickel smelters, show a positive correlation between the degree of pollution and accumulation of some heavy metals in different tissues, of different animals, such as urban pigeon - Columba livia [5], the magpies - pica [6], to swallow hirundo rustica [7].

Alterations in the plasma activity of enzymes used to detect hepatic disease in birds can reflect either hepatocellular injury or increased enzyme production. The liver performs a number of functions and plays an important role in metabolic processes, detoxification of xenobiotics, and hematopoiesis. High aspartate aminotransferase (AST) activity has been reported in the liver of birds. High AST activity has also been found in skeletal muscle, heart muscle, brain, and kidney [8].

In this study, we investigated biochemical parameters as alkaline phosphatase (AP), plasma alanin aminotransferase (ALT), aspartat aminotransferase (AST) and total proteins (TP) in blood plasma of house sparrow (Passer domesticus). The purpose of this study was the comparison of biochemical blood parameters of house sparrow (Passer domesticus), caught in industrially polluted areas (Mitrovica and Drenas town) and reference areas (Ujmir village) to assess environmental pollution with heavy metals.

\section{Materials and Methods}

\subsection{Study Areas}

The pollution of living environment in Mitrovica still presents an ecological problem (the area near foundry "Trepqa" closed since 2000). The main recourses of pollution in Mitrovica, in the past had as starting point different technological departures (metals foundry, refinery, flotation, factory of accumulations and sulfuric acid battery) of "Trepqa" combine and also superphosphates fertilizer factory. The work of these departments has made Mitrovica one of the most polluted cities in Europe. The pollution level can be illustrated from some informations by Popovac [9], who find that the quantity of the emitted lead dust everyday from the Trepça foundry in 1979 was 5 to 6 tons. The concentration of lead in air in Mitrovica from the same period was 20-30 $\mu \mathrm{g} / \mathrm{m}^{3}$. Trepça Foundry was closed in August $14^{\text {th }} 2000$ from the United States Forces. The research that was done from Shehu's [10], analysis of soil taken in the location around Mitrovica had noticed high concentration. More than 13 years have passed by but the pollution left from Trepça's activities, threatens seriously the local environment and people's health.

Drenas town is located 20 kilometres far from Prishtina (capital of Republic of Kosovo) in the West. The smelter (Ferronickel) has operated since 1982. Ferronikeli has three open pit mines: the Dushkaja mine with estimated reserves of 6.2 million tonnes; the Suka mine- 0.8 million tonnes and the Gllavica with 6.8 million tones. Ferronikeli smelter is wellknown for final production of Ferro- nickel.

In metallurgical processing the mineral base is treated by an oxide mineral of nickel (two sources) with the following average chemical structure: $\mathrm{Ni}+\mathrm{Co}=1.2 \% ; \quad \mathrm{Fe}=26.0 \%$; $\mathrm{SiO}_{2}=47.0 \% ; \mathrm{CaO}=2.5 \% ; \mathrm{Cr}_{2} \mathrm{O}_{3}=1.2 \% ; \mathrm{MgO}=11.0 \%$. The produced slag has the chemical structure as follows: $\mathrm{Ni}-0$ 08\%; $\mathrm{SiO}_{2}$ 55-57\%; $\mathrm{MgO} 10.0 \%$; Fe total 20\%; Ca) $4.0 \%$. The capacity of the smelter in the technological lines (rotating furnace and electrical furnace) is about $12.000 \mathrm{t}$ $\mathrm{Ni} /$ year [11]. In recent time, the smelter plant is active and it is known as "New CO Ferronickel".

\subsection{Blood Samples and Biochemical Analysis}

A blood collection was performed on 32 house sparrows (Passer domesticus) males and females, which were captured in Mitrovica town (situated close to smelter "Trepqa", down closed in year 2000), Drenas town (near the Ferronickel smelter, pollution area) and in rural area (Ujmir village, not contaminated area). The blood samples were collected in heparinised tubes by puncturing the alvar vein in the region of the carpal vein joint, after first removing feathers in the area and thoroughly cleaning the skin. We have analyzed: alkaline phosphatase (AP), plasma alanin aminotransferase (ALT), aspartat aminotransferase (AST) and total proteins (TP) in blood plasma of house sparrows (Passer domesticus). All biochemical analyses were conducted with an automated analyser (Ciba Express 550).

Statistics: Statistical elaboration of biochemical parameters was done with the method ANOVA by determining the average of each indicator, standard deviation. Significant differences were assumed at $\mathrm{p}<0.05$. For all statistical analyses, Sigma stat program was used.

\section{Results and Discussion}

Results of our study on the activity of transaminases (AST, ALT), alkaline phosphatase activity (AP) and total proteins (TP) in blood plasma of the house sparrow (Passer domesticus) caught in polluted industrial areas (Mitrovica and Drenas town) and reference area (Ujmir, village) are 
presented in table 1 and figure 1.

Table 1. Biochemical values of house sparrow (Passer domesticus) from polluted site (Mitrovica and Drenas town) and reference site (Ujmir village).

\begin{tabular}{llll}
\hline Blood & Reference site & Polluted site & Mitrovicë (10) \\
\cline { 2 - 4 } (biochemical parameters) & Ujmirë (10) & Drenas (12) & $209.8 \pm 199.7$ \\
\hline ALT $(U / L)$ & $104.8 \pm 68.9$ & $205.6 \pm 191.4$ & $998.3^{* *} \pm 619.1$ \\
AST $(U / L)$ & $379.6 \pm 284.8$ & $935.3^{* * *} \pm 654.2$ & $237.1 \pm 119.7$ \\
AP $(U / L)$ & $180.8 \pm 28.4$ & $251.7 \pm 53.4$ & $35.2 \pm 3.5$ \\
\hline TP $(g / L)$ & $41.3 \pm 10.1$ & $40.1 \pm 8.1$ & \\
\hline
\end{tabular}

Note: Values are expressed as means $\pm \mathrm{SD}$. In parentheses () number of birds. ${ }^{* *} \mathrm{P}<0.01 ;{ }^{* * *} \mathrm{P}<0.001$.

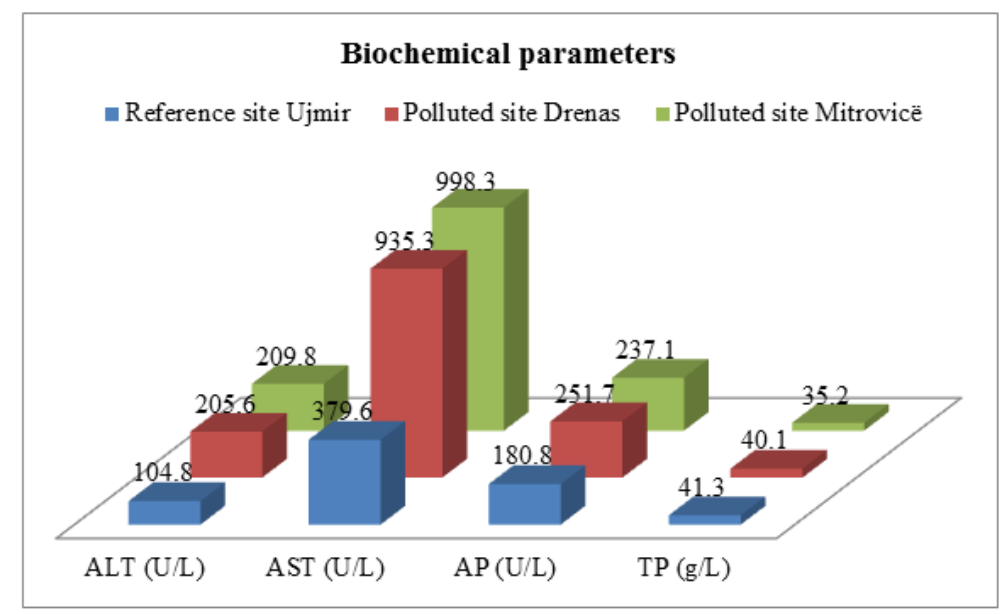

Fig. 1. Mean concentrations of enzymes $A L T, A S T, A P(U / L)$ and $T P(g / L)$.

In general, increases of plasma AST activity in birds are suggested when such activity is greater than $275 \mathrm{U} / \mathrm{L}$. Increases result from either hepatic or muscle injury, which allow the leakage of intracellular AST into the blood. Plasma AST activity is considered to be markedly increased when the activity is greater than $800 \mathrm{U} / \mathrm{L}$. Activity of this magnitude is suggestive of severe hepatic insult, especially in the presence of biliverdinuria or biliverdinemia. However, increased AST activity does not provide information about hepatic function. It is useful to evaluate Creatine kinase (CK) activity in conjunction with AST activity to differentiate between muscle and liver injury $[12,13]$. Increased plasma ALT activity may occur with muscle injury. Plasma ALT appears to have a longer half-life (mean of $11.99 \mathrm{hr}$ from muscle) compared with plasma CK (mean of $3.07 \mathrm{hr}$ from muscle); therefore, activity of ALT remains increased longer than CK does after muscle injury [14, 15]. Alanine aminotransferase (ALT) activity has been reported in the liver, skeletal muscle and many other tissues of birds, and leaks into blood when such tissues are injured.

Plasma ALT activity is considered to be neither a specific nor a sensitive test for hepatocellular injury in birds. Plasma ALT activity in most species of normal birds ranges from 19 to $50 \mathrm{U} / \mathrm{L}$ and may be more useful for the detection of hepatic disease in carnivorous birds. Plasma ALT activity increases with significant liver or muscle injury in birds (especially carnivores) and has no advantage compared with AST as a test for hepatocellular disease $[12,13]$..

Alkaline phosphatase activity occurs in multiple tissues including bone and intestine, and increased plasma AP activity results not from leakage of the enzyme but from increased cellular production. Plasma AP activity in birds results primarily from osteoblastic activity. Therefore, increases in the plasma AP activity are suggestive of skeletal growth, nutritional secondary hyperparathyroidism, healing fractures, and the preovulation condition of medullary calcification in hens. Plasma AP activity is not useful in the detection of hepatobiliary disease in birds. Aflatoxin B1induced liver necrosis and bile duct hyperplasia have not significantly increased the serum AP activity in the pigeon, cockatiel (Nymphicus hollandicus), great horned owl (Bubo virginianus), and red-tailed hawk (Buteo jamaicensis). Plasma AP activity appears to be a sensitive indicator of intestinal diseases, such as coccidial infections in the duodenum, jejunum, and cecum [14].

The normal plasma protein concentration in birds is less than that in mammals, generally ranging from 2.5 to $4.5 \mathrm{~g} /$ dL (25-45 g/L). Albumin, which represents $40-50 \%$ of the total plasma protein in birds, is produced in the liver. Other plasma proteins also produced in the liver include transport proteins, proteins of coagulation, fibrinogen, enzymes, and hormones. Immunoglobulin's produced by B lymphocytes and plasma cells represent a significant component of the total plasma protein concentration.

The normal plasma protein concentration is essential to the maintenance of the normal colloidal osmotic pressure, which preserves normal blood volume and $\mathrm{pH}$. Hens demonstrate a marked increase in plasma total protein concentration just before egg production [15, 16]. This estrogen-induced hyperproteinemia is associated with an increase in 
vitellogenin and lipoproteins, which are necessary for yolk production. These proteins are produced in the liver, transported in the blood, and incorporated into the oocytes of the ovary.

Capture myopathy in Sandhill cranes (Grus Canadensis tabida) was associated with increased plasma activity of CK, AST, and LDH within 1 hour of capture [17]. The peak activity of these enzymes occurred 3 days following capture and by 10-17 days, CK and LDH activities had returned to normal; however, plasma AST activities were still 2-5 times higher than normal reference values.

The increase level of transaminases (ALT, AST) in the blood plasma of sparrows from Mitrovica and Drenas are in accordance with results of Rozhaja [18], in case of treatment with lead in laboratory mice and in cases of environmental pollution with this metal. In cases of acute liver damage, enzyme ALT values are higher than the values of AST [19].'

\section{Conclusions}

The changes in the biochemical parameters show that the house sparrow (Passer domesticus) can be used as a bioindikator of environmental pollution with lead and nickel. The results obtained are correlative but further studies are warranted to investigate the mechanism of susceptibility of the house sparrow (Passer domesticus) to environmental pollution.

\section{References}

[1] Roux, E., Marra, P. 2007 "The presence and impact of environmental lead in Passerine birds along an urban to rural land use gradient". Arch Environ Contam Toxicol 53:261-268.

[2] Agency for Toxic Substances and Disease Registry. 1989. Agency for Toxic Substances and Disease Registry. Decision guideline for identifying substance-specific data needs related to toxicological profiles. Part V. Fed Regist 54:37619-37633.

[3] Miranda, M., Benedito, L., Blanco, I., Lopez, C., Merino, A., Lopez, M. 2009 "Metal accumulation in cattle raised in a serpentine - soil area: Relationship between metal concentrations in soil, forage and animal tissues". J. Trace Elem. Med. Biol., 23: 231- 238 .

[4] Scope, A., Frommlet, F., Schwendenwein, I. 2004 "Circadian and seasonal variability and influence of sex and race on eight clinical chemistry parameters in budgerigars (Melopsittacus undulatus, Shaw, 1805)". Res Vet Sci 78: 85-91.

[5] Elezaj, R. I., Selimi I. Q., Letaj Rr. K., Kurteshi, H.K.(2001): The effects of air pollution by heavy metals on biochemical and hematological parameters of the feral pigeons (Columba livia) from Mitrovica and Prishtina area. Federation of American Societies for Experimental Biology (The FASEB Journal). Abstract Number: Volume 15, Number 4, A 54. 50.5. March 7.
[6] Hahn, E., Optapczuk, P., Ellenberg, H., Stoeppler, M. (1985): Environmetal monitoring of heavy metals with birds as pollution integrating biomonitors II. Cadmium, Lead and Copper in Magpie (Pica Pica) Feathers from heavy polluted and control area. Proceedings of International Conference "Heavy Metals in the Environment". Vol.1, pp. 721-723, Athens- September.

[7] Grue, C. E., O'Shea, O.J. (1984): Lead concentrations and reproduction in Highway-nestin Barn Swallows. The Condor, 86: 383-389.

[8] Franson, J.C., Murray, H.C., Bunck, C. 1985 "Enzyme activities in plasma, kidney, liver, and muscle of five avian species". J Wildlife Dis. 21:33-9.

[9] Popovac, D., Colakovic, B., Popovac, R., Saljic, L., Rodorovic, P. 1981 "Environmental poll-ution in the industrial region of Mitrovica e Kosoves and possible effects on human health". Acta. Biol. Med. Exp., 6, 61-65.

[10] Shehu, I., Demaku S., Arbneshi, T., Jusufi, S., Shala, F., Dobra, B. 2011 "Heavy Metals in Landfill Waste of Trepça, after Flotation Process as Pollutants of Water and Soil". J. Int. Environmental Application and Science. 6 (3): 429 - 433.

[11] Rizaj, M., Beqiri, E., McBow, Z., Kongoli, F. 2008 “The mineral base and productive capacities of metals and nonmetals of Kosovo". JOM. vol.60 No.8, 18-22.

[12] Lumeij, J.T. 1987. "A Contribution to Clinical Investigative Methods for Birds, with Special Reference to the Racing Pigeon (Columbia livia domestica)" [thesis]. Utrecht, Proefschrift.

[13] Lumeij, J.T. 1994 "Avian clinical enzymology". Semin Avian Exotic Pet Med 3: 14-24.

[14] Lumeij, J.T., De Bruijne, J.J., Slob, A. 1998. "Enzyme activities in tissues and elimination half-lives of homologous muscle and liver enzymes in the racing pigeon (Columbia livia domestica)". Avian Pathol 17: 851-64.

[15] Kogut, M.H., Powell, K.C. 1993 "Preliminary findings of alterations in serum alkaline phosphatase activity in chickens during coccidial infections". J Comp Path 108: 113-19.

[16] Johnson, A.L. 1986 "Reproduction in the female. In: Stukie PD (ed.)", Avian Physiology. New York: Springer-Verlag, pp. 403-31.

[17] Businga, N.K., Langenberg, J., Carlson, L. 2007 "Successful treatment of capture myopathy in three wild greater sandhill cranes [Grus Canadensis tabida]". J Avian Med Surg 21: 2948.

[18] Rozhaja, D.A., Jablanoviq, M. 1983 "Ndotja dhe mbrojtja e ambientit të njeriut". Enti i teksteve dhe mjeteve mësimore, Prishtinë.

[19] Wolf, P.L., Williams, D., Von Der Muehll, E. 1973 "Practical clinical enzymology: Techniques and interpretations and biochemical profiling" pp. 215-226. John Wiley and Sons, Inc., New York. 